\title{
Respiration rate and ethylene production of fresh cut lettuce as affected by cutting grade
}

Juan A. Martínez

Plant Production Department, Technical University of Cartagena, Paseo Alfonso XIII, 52, 30203 Cartagena, Spain

Angel Chiesa

Horticulture Department, Faculty of Agronomy, University of Buenos Aires, Av. San Martín 4453, 1417 Buenos Aires, Argentine

Francisca Tovar, Francisco Artés

Postharvest and Refrigeration Group, Food Engineering Department, Technical University of Cartagena, Paseo Alfonso XIII, 48, 30203 Cartagena, Spain, e-mail: fr.artes@upct.es

\begin{abstract}
For designing optimal polymeric films for modified atmosphere packaging of whole heads as well as for minimally fresh processed (fresh-cut) Iceberg lettuce 'Coolguard', the effect of several cutting grades on respiration rate (RR) and ethylene production at $5^{\circ} \mathrm{C}$ was studied. According to common industrial practices cutting grades less than $0.5 \mathrm{~cm}$, between 0.5 and $1 \mathrm{~cm}$, and $2 \mathrm{~cm}$ length were selected. Results from four experiments were compared to those obtained for whole heads in which a homogenous range of 6 to 8 $\mathrm{ml} \mathrm{CO} \mathrm{kg}^{-1} \mathrm{~h}^{-1}$ in RR was found. Compared to whole heads, in fresh-cut lettuce the RR was 2-fold higher. The lowest cutting grade showed the highest respiration rate, and no significant differences in RR among lettuce pieces of intermediate and the highest grades were found. No ethylene production was detected in whole heads, while in minimally processed lettuce pieces only traces were found. For avoiding risks of anaerobic respiration and excessive $\mathrm{CO}_{2}$ levels within packages containing fresh-cut lettuce pieces lower than $0.5 \mathrm{~cm}$ length, films with relatively high $\mathrm{O}_{2}$ permeability like standard polypropylene or low-density polyethylene must be selected.
\end{abstract}

Key words: Lactuca sativa, minimal processing, respiratory activity, ethylene emission

\section{Introduction}

In recent years minimally fresh processed fruit and vegetables are increasingly being consumed around the world due to the increase of fresh fruits and vegetables demand free from additives, provided of convenience and with high overall quality and safety. Minimally fresh processed fruit and vegetables are prepared by using light methods such as washing, cutting, grating, pulling the leaves off, etc, and packed at chilling temperatures 
Vol. 14 (2005): 354-361.

under films usually of selective permeability to gases, in order to generate modified atmosphere packaging (MAP) conditions. This kind of plant commodities are very perishable, with risk of a quick deterioration and quality detriment, and a high care must be applied in their manufacture, distribution and retail sale. For keeping quality of fresh-cut products, they must be prepared and handled in well designed factories by taking great care and hygiene at chilling temperature, and kept under MAP at 0 to $5^{\circ} \mathrm{C}$ until consumption (Watada et al. 1990, Artés 1995, Francis et al. 1999, Artés 2000, Artés and Artés-Hernández 2000, 2004).

The design of an optimum film for MAP implies the knowledge of the gaseous barrier properties of films and the respiration rate (RR) of the product involved. Among the characteristics of a polymeric film for MAP it must be hermetically sealed in order to avoid cross microbial contamination, assuring the hygienic conditions and limiting water vapour transmission. Obviously, to generate a suitable steady state within packages due to the interaction between product respiration and film permeability, the polymer must have an adequate selective permeability to $\mathrm{O}_{2}\left(\mathrm{P}_{\mathrm{O} 2}\right)$ and to $\mathrm{CO}_{2}$ $\left(\mathrm{P}_{\mathrm{CO} 2}\right)$ according to physiological requirements of the commodity (Artés 1993, Artés and Martínez 1998, Chiesa et al. 2004). The product shelf-life under MAP can be increased by reducing the $\mathrm{O}_{2}$ level within package, due to its favourable effect on decreasing the metabolism and RR. However, levels of $\mathrm{O}_{2}$ below $1 \mathrm{kPa}$ can led to anaerobic respiration and off-flavour production (Gorny 1997a) and can permit the growth of aerotolerant anaerobes such as LAB bacteria and anaerobic psychrotrophic pathogens (Marth 1998). Polyolefin films, including polypropylene (PP) and low density polyethylene (LDPE) are commonly used in MAP technique, for fresh intact as well as for fresh-cut commodities. This is due to their suitable $\mathrm{P}_{\mathrm{O} 2}$ and $\mathrm{P}_{\mathrm{CO} 2}$ and selectivity $\left(\mathrm{P}_{\mathrm{CO} 2} / \mathrm{P}_{\mathrm{O} 2}\right.$ ratio) for providing optimal storage conditions (Exama et al. 1993, Artés et al. 1998b, Artés and Martínez 1998).

Cutting vegetables for minimal processing provokes a wound stress response, and compared to those of the intact product the metabolism and the RR and ethylene emission are commonly in- creased, and undesirable enzymatic reactions are stimulated which result in browning (Mattila et al. 1993, Artés et al. 1998a). The aim of the present work was to evaluate the effect of different grades of minimal processing, by changing the cutting size, on the RR and ethylene production of Iceberg lettuce.

\section{Material and methods}

\section{Plant material}

Iceberg lettuce (Lactuca sativa L.) is currently the most important raw material of the minimal fresh processing industry around the world, and 'Coolguard' one of the better-adapted cultivars for minimal processing. Heads of the 'Coolguard' growing under Mediterranean climate were harvested from January to April in a commercial farm located in Campo de Cartagena, Murcia (Spain). Heads were harvested according to commercial practices. Lettuces were packed in plastic boxes and immediately transported $40 \mathrm{~km}$ by car to the laboratory where they were placed in a cold room at $5^{\circ} \mathrm{C}$, until handling on next day.

\section{Minimal fresh processing}

The processing of the heads was accomplished within a disinfected cold room at $10^{\circ} \mathrm{C}$. Heads with any defect or disorder including wound on the external leaves were discarded, and by using a wellsharp knife the stems were eliminated. Hereafter, heads were divided in two parts by mean of a longitudinal cut on the central axis. On each part, transverse cuts at regular intervals from the top to the bottom were performed.

According to common industrial practices in Spain, the following cutting grades were selected: less than $0.5 \mathrm{~cm}$, between 0.5 and $1 \mathrm{~cm}$, and $2 \mathrm{~cm}$. In each head, the number of cutting pieces was between 50 and 70 in the smallest cutting grade, between 20 and 40 in the intermediate, and between 
Martínez, J.A. et al. Respiration rate and ethylene production of fresh cut lettuce

10 and 15 in the greatest. Therefore, the larger the cutting grade is the smaller the number of pieces is. Hereafter, all pieces of the same cutting grade were mixed and homogenised, and three replicates per treatment were randomly done.

\section{Respiration rate and ethylene production}

Three heads of similar appearance and free from defects were randomly selected to compare the respiratory pattern of whole lettuce and fresh-cut pieces. External leaves with any damage were discarded, and in order to eliminate the slight browning area a thin cutting in the bottom of the stem was performed.

For determining the RR a flow-through system was applied. A known flow of humidified air passed through a glass jar containing the product. All the experimental set up was located in a cold room at $5^{\circ} \mathrm{C}$ and $90-95 \%$ relative humidity. After a short period of time, the amount of $\mathrm{CO}_{2}$ emitted by the product in the glass jar equals the amount of the gas flowing from the glass jar. For avoiding the respiration inhibition the air flow rate was adjusted in order to accumulate less than $0.2 \mathrm{kPa} \mathrm{CO}_{2}$ within the respiratory chamber. When the equilibrium was reached, the production of $\mathrm{CO}_{2}$ was calculated from the weight of the lettuce, the flow rate, and the difference in concentration between the inlet and outlet, according to the Equation 1 (Saltveit 1982).

$$
\mathrm{ml} \mathrm{CO} \mathrm{Cg}^{-1} \bullet \mathrm{h}^{-1}=\mathrm{kPaCO}_{2} \bullet 10 \bullet \mathrm{C} \bullet \mathrm{W}^{-1}
$$

where $\mathrm{ml} \mathrm{CO} \mathrm{CO}_{2} \bullet \mathrm{kg}^{-1} \bullet \mathrm{h}^{-1}$ is the volume of $\mathrm{CO}_{2}$ emitted by aerobic respiration per kg of lettuce and hour, $\mathrm{kPaCO}_{2}$ is determined within the respiratory chamber, $\mathrm{C}$ is the gas flowing rate $\left(1 \bullet \mathrm{h}^{-1}\right)$ into the glass jar, and $\mathrm{W}$ is the weight of the lettuce in $\mathrm{kg}$.

Due to its very low amount the ethylene production was monitored, without reaching inhibitory values of $\mathrm{CO}_{2}$, by using a static system (Saltveit 1982). The ethylene emission rate was calculated according to the Equation 2.

$$
\mu \mathrm{l} \mathrm{C}_{2} \mathrm{H}_{4} \bullet \mathrm{kg}^{-1} \bullet \mathrm{h}^{-1}=\mathrm{ppm} \mathrm{C}_{2} \mathrm{H}_{4} \bullet \mathrm{C} \bullet \mathrm{W}^{-1}
$$

The $\mathrm{CO}_{2}$ and $\mathrm{C}_{2} \mathrm{H}_{4}$ levels were determined by mean of a gas chromatograph (Perkin Elmer, Connecticut, USA) equipped with a thermal conductivity detector a flame ionization detector, and a Porapak QS column 80/100 of $1.2 \mathrm{~m} \times 1 / 8 \mathrm{~s}$. The gas samples collected were $1 \mathrm{ml}$ for $\mathrm{CO}_{2}$ and $5 \mathrm{ml}$ for $\mathrm{C}_{2} \mathrm{H}_{4}$. The measurement error was $0.1 \%$ for $\mathrm{CO}_{2}$ and $1.5 \%$ for $\mathrm{C}_{2} \mathrm{H}_{4}$, with a detection limit of $0.01 \mathrm{ppm}$ of $\mathrm{C}_{2} \mathrm{H}_{4}$ and $0.01 \mathrm{kPa}$ of $\mathrm{CO}_{2}$. Levels of both gases were determined three times every day.

\section{Experimental design}

A factorial design of repeated measurements was applied. Throughout each experiment gas samples were taken every day from the same experimental units. The four experiments were independently analysed. An ANOVA with the software Statgraphics Plus for Windows 5.1 (Statistical Graphics Corp., Englewood Cliffs, USA) was applied. When appropriated, for separating means the LSD (Least Significant Difference) test was executed.

\section{Results and discussion}

A lower RR in whole lettuce than in fresh cut lettuce pieces was found. In whole heads placed at $5^{\circ} \mathrm{C}$ a range of homogenous values between 6 to 8 $\mathrm{ml} \mathrm{CO} \mathrm{kg}^{-1} \bullet \mathrm{h}^{-1}$ was determined (Figs. 1 and 2). Our results are in the same range than those early reported for whole heads of unspecified cultivars (Kader 2002). This author classified lettuce as a commodity with moderate $\mathrm{RR}$ values, ranging from 5 to $10 \mathrm{ml} \mathrm{CO} \mathrm{kg}^{-1} \bullet \mathrm{h}^{-1}$ at $5^{\circ} \mathrm{C}$. Le Ster (1995) reported a RR of $9 \mathrm{ml} \mathrm{CO} \mathrm{kg}^{-1} \bullet \mathrm{h}^{-1}$ for whole lettuce at $10^{\circ} \mathrm{C}$.

Whole heads showed a slight decrease in RR from about $10 \mathrm{ml} \mathrm{CO}_{2} \mathrm{~kg}^{-1} \bullet \mathrm{h}^{-1}$ at harvest to 5-6 $\mathrm{ml} \mathrm{CO} \mathrm{kg}^{-1} \bullet \mathrm{h}^{-1}$ during the first 6 days at $5^{\circ} \mathrm{C}$, without significant differences until the end of the 
Vol. 14 (2005): 354-361.

(a)

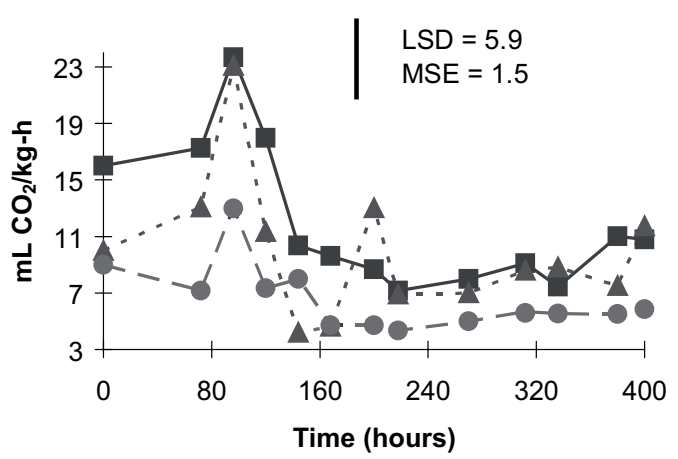

(c)

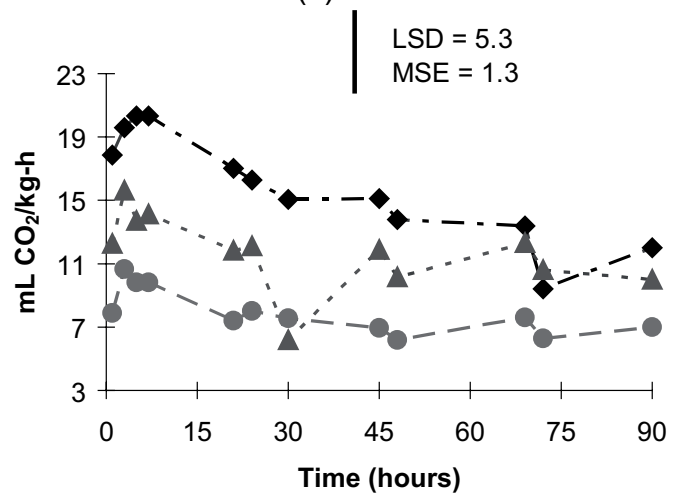

$-\diamond-<0.5 \mathrm{~cm}$

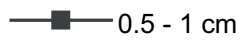

(b)

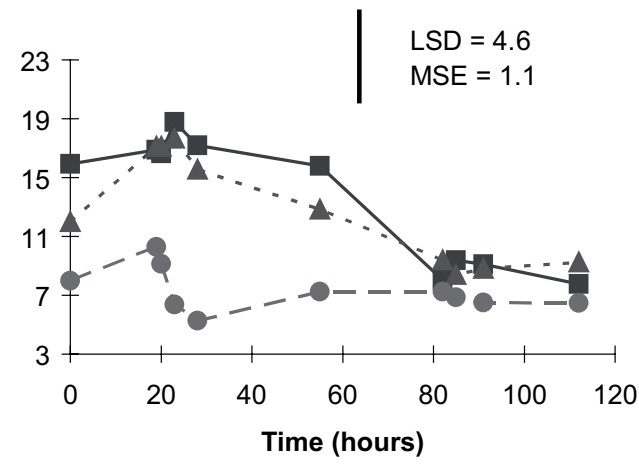

(d)

$\mathrm{LSD}=6.2$

$\mathrm{MSE}=1.6$

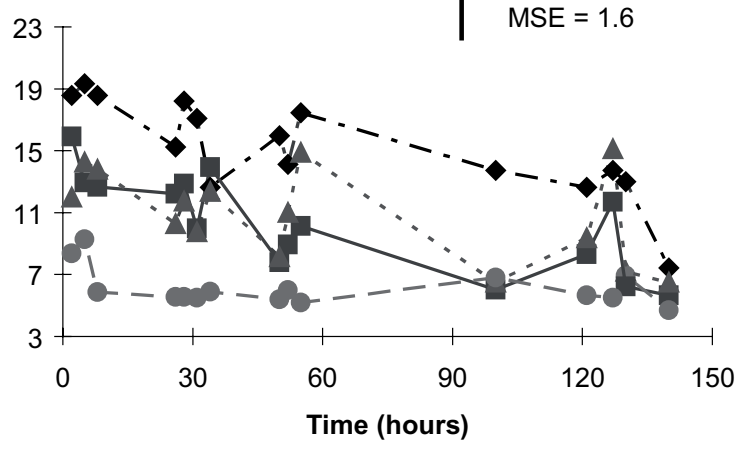

$=-\cdots 2 \mathrm{~cm} \quad-\bullet-$ whole

Fig. 1. Respiration rate of whole heads of Iceberg lettuce 'Coolguard' and minimally fresh processed with three cutting grades during storage at $5^{\circ} \mathrm{C}$ and $90-95 \%$ relative humidity in four experiments. (a) - 1st experiment, (b) - 2nd experiment, (c) - 3rd experiment, (d) - 4th experiment. Vertical lines represent the interval least significant difference (LSD) (P $\leq 0.05)$. MSE is the standard error of the mean.

storage period (Fig. 1b, c, d). These values confirm results found by Hardenburg et al. (1986) who reported a decrease of the RR at $5^{\circ} \mathrm{C}$ in whole heads of Iceberg lettuce 'Great Lakes' from around $10 \mathrm{ml}$ $\mathrm{CO}_{2} \mathrm{~kg}^{-1} \bullet \mathrm{h}^{-1}$ at harvest to $7 \mathrm{ml} \mathrm{CO} \mathrm{kg}^{-1} \bullet \mathrm{h}^{-1}$ after elapsing 5 days. On the other hand, our results agree with those reported by Cantwell (1995), who did not detect a significant decrease in RR of whole crisphead lettuce during 9 days at temperatures between 2.5 and $10^{\circ} \mathrm{C}$.
The influence of the processing grade and storage duration on the RR of lettuce pieces are shown in Table 1. Throughout the four experiments, both factors showed a significant effect (at $\mathrm{P} \leq 0.001$ with $75 \%$ explained data). The RR increased at least 2-fold in whole heads during a few hours after cutting as a consequence of minimal processing (Fig. 1), because the wound of the plant tissues provoked by cutting induce a free diffusion of $\mathrm{CO}_{2}$ and $\mathrm{O}_{2}$ through tissues. After that, the normal gas 
Martínez, J.A. et al. Respiration rate and ethylene production of fresh cut lettuce

Table 1. Analysis of variance (expressed as total sum of square percentage and probability) of the respiration rate of different grade of processing in Iceberg lettuce 'Coolguard' and in whole heads stored at $5^{\circ} \mathrm{C}$ in four experiments.

\begin{tabular}{lrlrlrrrr}
\hline Source of variation & \multicolumn{7}{c}{ Experiment and degree of freedom } \\
\cline { 2 - 9 } & $\mathrm{dF}$ & Exp. $1^{1}$ & $\mathrm{dF}$ & Exp. 2 & $\mathrm{dF}$ & Exp. 3 & $\mathrm{dF}$ & Exp. 4 \\
\hline Grade of cutting & 2 & $18.52^{* * *}$ & 2 & $34.08^{* * *}$ & 2 & $54.31 * * *$ & 3 & $56.56^{* * *}$ \\
Storage period & 10 & $51.61^{* * *}$ & 8 & $37.48^{* * *}$ & 10 & $20.71^{* * *}$ & 14 & $17.21^{* * *}$ \\
Residual & 78 & 30.64 & 63 & 28.66 & 86 & 24.97 & 112 & 25.60 \\
\hline
\end{tabular}

*** Significant at $\mathrm{P} \leq 0.001, \mathrm{dF}=$ degree of freedom

${ }^{1}$ The nomenclature of the experiment running is the same to those of the Figures. The levels of the factors in each experiment are illustrated on the Figures 1 and 2.

diffusion predominated and the RR slightly decreased (Fig. 1). This initial increase was the highest in the thinnest cutting grade, very probably due to a higher cutting surface of plant tissues and therefore the diffusive gas exchange increased.

Mean values of RR ranged between 10 and 16 $\mathrm{ml} \mathrm{CO} \mathrm{CO}_{2} \bullet \mathrm{kg}^{-1} \bullet \mathrm{h}^{-1}$ at $5^{\circ} \mathrm{C}$ for minimally processed lettuce pieces. Le Ster (1995) reported a result slightly higher of $22 \mathrm{ml} \mathrm{CO}_{2} \bullet \mathrm{kg}^{-1} \bullet \mathrm{h}^{-1}$ at $10^{\circ} \mathrm{C}$ for sliced lettuce, very probably due to higher temperature. No significant differences between cutting grade of $0.5-1 \mathrm{~cm}$ and $2 \mathrm{~cm}$ were found (Fig. 2a, b, d). The RR corresponding to both cutting grades was higher than in whole heads and lower than in lettuce pieces of less than $0.5 \mathrm{~cm}$. Moreover, it was found that the increase of RR in fresh cut lettuce was highest in the thinnest grade (Fig. 2c, d). This difference can be due to the intensity and severity of the wound on lettuce tissues due to cutting in the smallest grade. These large wounds were the cause of the RR increase described below (Fig. 1). It has been also reported than RR of minimally processed vegetables is affected by the cutting style too (Mattila et al. 1993, Chu and Wang 2001).

At the same time and as a response of cutting, the increase in ethylene production stimulated the RR. In our experiments ethylene production was about $0.05 \mu \mathrm{l} \bullet \mathrm{kg}^{-1} \bullet \mathrm{h}^{-1}$ in the cutting grade less than $0.5 \mathrm{~cm}$ immediately after cutting, for decreasing to $0.02 \mu \mathrm{l} \bullet \mathrm{kg}^{-1} \bullet \mathrm{h}^{-1} 24$ hours later (Table 2). These results agree with findings of Yang and Pratt (1978) who described a peak in ethylene emission due to wounding after a latency period of 10 to 30 min, followed by a decrease in the following hours. Our results also confirm those of Kim and Wills
(1995) reporting that lettuce produces little ethylene, less than $0.1 \mu \mathrm{l} \bullet \mathrm{kg}^{-1} \bullet \mathrm{h}^{-1}$. However, neither ethylene emission was detected in whole heads nor in the cutting grade of $2 \mathrm{~cm}$, and only traces were detected immediately after cutting in lettuce pieces of $0.5-1 \mathrm{~cm}$ (Table 2).

The selection of polymeric films for packaging depends on the RR of the commodities according to the cutting grade and style. The smaller the cutting grade is, the higher $\mathrm{P}_{\mathrm{CO} 2}$ and $\mathrm{P}_{\mathrm{O} 2}$ must be. The $\mathrm{P}_{\mathrm{CO} 2}$ must be relatively high in order to avoid risk of disorders due to $\mathrm{CO}_{2}$ accumulation within packages. In fact, severity of brown stain increased when $\mathrm{CO}_{2}$ levels around whole lettuce heads were higher than $2 \mathrm{kPa}$ (Artés and Martínez 1998, Artés et al. 1999) or higher than $18 \mathrm{kPa}$ in minimally fresh processed Iceberg lettuce (Mateos et al. 1993). On the other hand, $\mathrm{O}_{2}$ levels lower than 1 $\mathrm{kPa}$ could induce risks of anaerobiosis and off-flavours (Artés et al. 1999).

From the present results about RR and according to previous reports (Artés and Martínez 1998, Artés et al. 1998b), the recyclable polyolefins PP of $24 \mu \mathrm{m}$ thickness and particularly LDPE of 14 $\mu \mathrm{m}$ thickness, could be both adequate for packaging fresh-cut 'Coolguard' for all cutting grades studied. At $2^{\circ} \mathrm{C}$ the $\mathrm{P}_{\mathrm{O} 2}$ of the PP was $40 \mathrm{ml} \bullet \mathrm{mm} \cdot$ $\mathrm{m}^{-2} \bullet$ day $^{-1} \bullet$ atm $^{-1}$ and the $\mathrm{P}_{\mathrm{CO} 2}$ was $121 \mathrm{ml} \bullet \mathrm{mm} \bullet$ $\mathrm{m}^{-2} \bullet$ day $^{-1} \bullet$ atm $^{-1}$, while those of LDPE was 163 and 597 respectively. Therefore, the selectivity was 3.0 in PP and 3.7 in LDPE. In fact, according to the general equation of gas exchange under a MAP system which gives Equation 3 (Mannapperuma et al. 1989), it can be obtained the effect of selectivity on gas conditions and vice versa 
Vol. 14 (2005): 354-361.

(a)

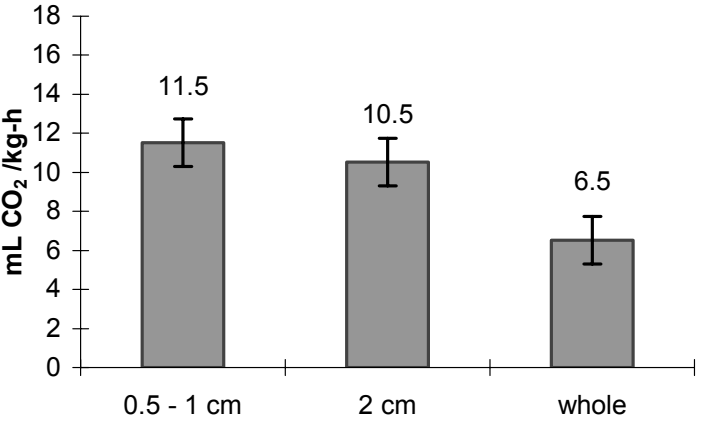

(c)

$\mathrm{LSD}=0.8$

MSE $=0.5$

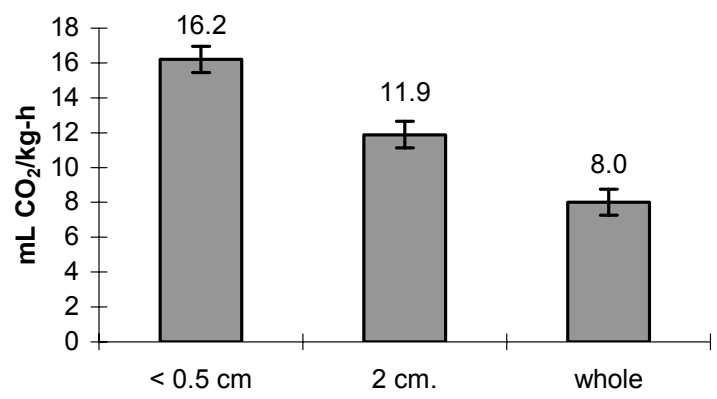

(b)

$\mathrm{LSD}=1.1$

$\mathrm{MSE}=0.8$

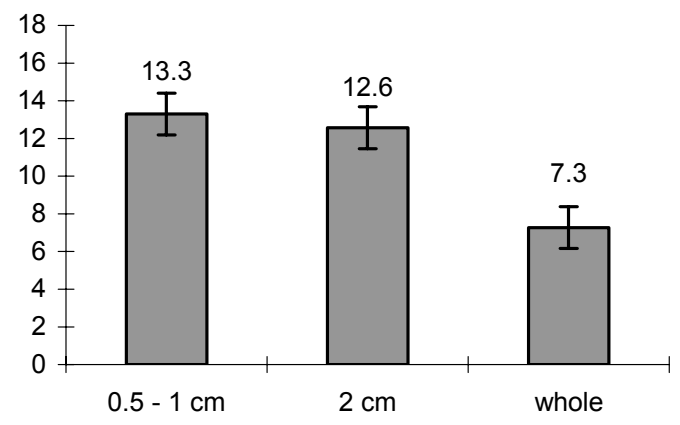

(d)

$\mathrm{LSD}=0.8$

MSE $=0.5$

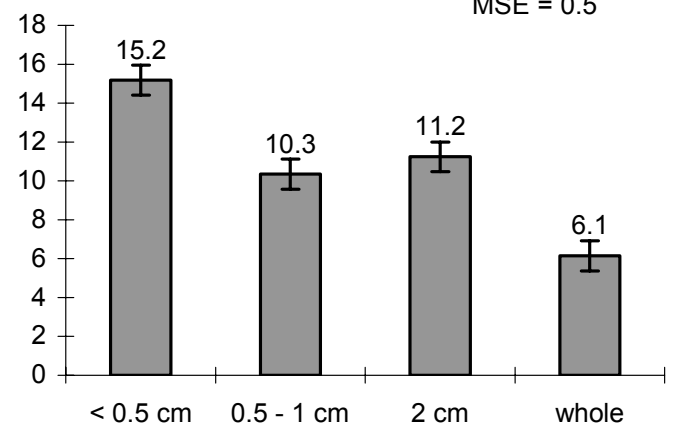

\section{Cutting grade}

Fig. 2. Means of whole heads respiration rate of Iceberg lettuce 'Coolguard' and minimally fresh processed with three cutting grades during storage at $5^{\circ} \mathrm{C}$ and $90-95 \%$ relative humidity in four experiments. (a) -1 st experiment, (b) -2 nd experiment, (c) - 3rd experiment, (d) - 4th experiment. Vertical lines represent the interval least significant difference (LSD) $(\mathrm{P} \leq 0.05)$. MSE is the standard error of the mean.

Table 2. Ethylene production (ppm) in whole and fresh processed Iceberg lettuce 'Coolguard' immediately after cutting and after 24 hours of processing.

\begin{tabular}{lcccc}
\hline Time elapsed from & & \multicolumn{3}{c}{ Cutting grade, cm } \\
\cline { 3 - 5 } processing (hours) & & & & \\
\cline { 3 - 5 } & Whole & $<0.5$ & $0.5-1$ & 2 \\
\hline 0 & nd & 0.05 & 0.02 & nd \\
24 & nd & 0.02 & nd & nd \\
\hline
\end{tabular}

nd $=$ no detected

$$
\begin{aligned}
& \mathrm{b} \bullet \mathrm{W} \bullet \mathrm{R}_{\mathrm{O} 2}=\mathrm{P}_{\mathrm{O} 2} \bullet \mathrm{A} \bullet\left(\mathrm{c}_{\mathrm{O} 2}-\mathrm{x}_{\mathrm{O} 2}\right) \\
& \mathrm{b} \bullet \mathrm{W} \bullet \mathrm{R}_{\mathrm{CO} 2}=\mathrm{P}_{\mathrm{CO} 2} \bullet \mathrm{A} \bullet\left(\mathrm{c}_{\mathrm{CO} 2}-\mathrm{x}_{\mathrm{CO} 2}\right)
\end{aligned}
$$

where $\mathrm{b}$ is the film thickness ( $\mathrm{mm})$; $\mathrm{W}$ is the weight of product within package $(\mathrm{kg}) ; \mathrm{R}$ is the $\mathrm{RR}(\mathrm{ml}$ gas $\bullet \mathrm{kg}^{-1} \bullet$ day $\left.^{-1}\right)$; $\mathrm{P}$ is the film permeability $(\mathrm{ml} \bullet$ $\mathrm{mm} \bullet \mathrm{m}^{-2} \bullet$ day $\left.^{-1} \bullet \mathrm{atm}^{-1}\right) ; \mathrm{A}$ is the area of the film $\left(\mathrm{m}^{2}\right)$; $\mathrm{c}$ is the gas partial pressure in the ambient atmosphere (usually air); and $\mathrm{x}$ the is the partial pressure in the package atmosphere. 
This model equates the steady state gas flow rates to equilibrium $\mathrm{RR}$ of the product. On the other hand, from Equations 3 and 4, it can be obtained:

$$
\mathrm{x}_{\mathrm{CO} 2}=\mathrm{c}_{\mathrm{CO} 2}+1 \bullet \beta^{-1} \bullet\left(\mathrm{c}_{\mathrm{O} 2}-\mathrm{x}_{\mathrm{O} 2}\right) \bullet \mathrm{R}_{\mathrm{CO} 2} \bullet \mathrm{R}_{\mathrm{O} 2}{ }^{-1}
$$

where $\mathrm{c}_{\mathrm{CO} 2}$ is constant and practically $0 ; \mathrm{R}_{\mathrm{CO} 2} \bullet$ $\mathrm{R}_{\mathrm{O} 2}{ }^{-1}$ is the respiratory quotient (usually equal to 1 ), and $\beta$ is the selectivity. Therefore:

$$
\mathrm{x}_{\mathrm{CO} 2}=1 \bullet \beta^{-1} \bullet\left(\mathrm{c}_{\mathrm{O} 2}-\mathrm{x}_{\mathrm{O} 2}\right)
$$

Equation 6 has a linear trend with a slope of $\beta^{-1}$. MAP stored chopped or shredded Iceberg lettuce needs $\mathrm{O}_{2}$ levels between 0.5 to $3 \mathrm{kPa}$ and $\mathrm{CO}_{2}$ levels between 10 to $15 \mathrm{kPa}$ (Gorny 1997b). According to this, the permeability ratios were obtained from simulating extreme values of respiratory gases within packages and substituting in Equation 6 for determining $\beta$. These values were:

$$
\begin{aligned}
& \mathrm{x}_{\mathrm{CO} 2}=0.15 \text { and } \mathrm{x}_{\mathrm{O} 2}=0.005 \Rightarrow \beta=1.4 \\
& \mathrm{x}_{\mathrm{CO} 2}=0.10 \text { and } \mathrm{x}_{\mathrm{O} 2}=0.03 \Rightarrow \beta=1.8 \\
& \mathrm{x}_{\mathrm{CO} 2}=0.15 \text { and } \mathrm{x}_{\mathrm{O} 2}=0.03 \Rightarrow \beta=1.2 \\
& \mathrm{x}_{\mathrm{CO} 2}=0.10 \text { and } \mathrm{x}_{\mathrm{O} 2}=0.005 \Rightarrow \beta=2.1
\end{aligned}
$$

$\beta$ values obtained were lower than 3 , but due to temperature throughout the distribution chain is rarity lower than $5^{\circ} \mathrm{C}$, and the optimal gas conditions are quite close to damage atmosphere, it is recommendable to reach $\mathrm{O}_{2}$ levels higher than 3 $\mathrm{kPa}$ within packages under these conditions and particularly when the thinnest cutting is considered. In fact, the most important gas affecting lettuce quality is $\mathrm{O}_{2}$ and $3 \mathrm{kPa} \mathrm{O}$ has been reported as reducing browning in shredded lettuce (Mateos et al. 1993). However, the benefits of high $\mathrm{CO}_{2}$ are not a critical factor. In this manner, in our opinion an atmosphere within package of $3 \mathrm{kPa} \mathrm{O}_{2}$ plus 5-6 $\mathrm{kPa} \mathrm{CO}$ is commercially useful. This atmosphere could be feasible by using an adequate design of PP (selectivity of 3.0) and LDPE (selectivity of 3.7) by substituting values in Equation 6 and considering appropriate weight of product, area of package, thickness of the film and, of course, the value of RR for reaching optimal MAP conditions according to Equations 3 and 4.

\section{Conclusions}

Throughout storage of whole lettuce heads at $5^{\circ} \mathrm{C}$ no noticeable changes in RR was found. However, the minimal fresh processing induced a sudden increase of RR immediately after cutting, which slightly decreased throughout cold storage at $5^{\circ} \mathrm{C}$, mainly in the great sharp processing.

According to values of RR and ethylene production, fresh cut Iceberg lettuce 'Coolguard' can be classified in two categories: the thinnest processing with a cutting grade less than $0.5 \mathrm{~cm}$ and the grade ranging from 0.5 to $2 \mathrm{~cm}$. The highest $\mathrm{CO}_{2}$ emission was found in the smallest cutting grade (less than $0.5 \mathrm{~cm}$ ). Consequently this processing grade will demand polymeric packages provided with higher $\mathrm{P}_{\mathrm{CO} 2}$ and $\mathrm{P}_{\mathrm{O} 2}$ at chilling temperatures like standard PP or LDPE in order to avoid an excess of $\mathrm{CO}_{2}$ level and risks of anaerobiosis within packages.

Acknowledgements. The authors acknowledge the Fundación Séneca de la Región de Murcia (Spain), Projects AGR 3-02667/FS/02 and 00553/PI/04 co-financed by FEDER for financial support. Thanks are also due to CEBAS-CSIC and to Kernel Export S.L. for providing facilities and lettuces respectively.

\section{References}

Artés, F. 1993. Diseño y cálculo de polímeros sintéticos de interés para la conservación hortofrutícola en atmósfera modificada. In: Colegio Oficial de Ingenieros Agrónomos (ed.). Nuevo curso de ingeniería del frío. A. Madrid Ediciones. 2nd edition. Madrid. p. 427-453.

Artés, F. 1995. Innovaciones en los tratamientos físicos modulados para preservar la calidad hortofrutícola en la postrecolección. I. Pretratamientos térmicos. Revista Española de Ciencia y Tecnología de Alimentos 35, 1: 45-64.

Artés, F. 2000. Productos vegetales procesados en fresco. In: Lamúa M. (ed.). Aplicación del frío a la conservación de productos perecederos. p. 127-141.

Artés, F., Castañer, M. \& Gil, M.I. 1998a. Enzymatic browning in minimally processed fruit and vegetables. Food Science and Technology International 4, 6: 377-389.

Artés, F., Marín, J.G. \& Martínez, J.A. 1998b. Permeability rates of films for modified atmosphere packaging of re- 
Vol. 14 (2005): 354-361.

spiring foods. In: Nicolaï, B.M. \& Baerdemaeker, J.D. (eds.). Food quality modelling. Belgium, European Commission. p. 153-158.

Artés, F. \& Martínez, J.A. 1998. Gas transmission characteristics of different films used for packaging intact and minimally processed fruit and vegetables. In: Ben-Yehoshua, S. (ed). International Congress for Plastics in Agriculture. Tel-Aviv, Israel. p. 481-486.

Artés, F., Martínez, J.A. \& Marín, J.G. 1999. Quality changes in minimally processed 'Romaine' lettuce as affected by several treatments. In: Hägg, M. et al. (eds.). Agrifood quality II. Quality management of fruits and vegetables. The Royal Society of Chemistry. p. 115-118.

Artés, F. \& Artés-Hernández, F. 2000. Fundamentos y diseño de instalaciones para procesado en fresco de hortalizas. Alimentación, Equipos, Tecnología 3: 135141.

Artés, F. \& Artés-Hernández, F. 2004. Designing new industrial factories for minimal fresh processing of plant products. In: Proceedings of the CIGR International Conference on Agricultural Engineering. Beijing, China. Paper no. 20-133A. Available on CD ROM.

Cantwell, M. 1995. Fresh-cut product biology requirements. University of California. Perishables Handling Newsletter 81: 4-6.

Chiesa, A., Seija, E., Moccia, S. \& Frezza, D. 2004. Fresh cut lettuce (Lactuca sativa L.) quality as affected by packaging material. European Journal of Horticultural Science 69, 1:21-28.

Chu, C.L. \& Wang, S.L. 2001. Effect of cutting style, lowoxygen atmosphere and cold temperature on the respiration rate of minimally processed vegetables. In: BenArie, R. \& Philosoph-Hadas, S. (eds.). Proceedings of the 4th International Conference on Postharvest Science. ISHS Commission Postharvest 2: 691-692.

Exama, A., Arul, J., Lencki, R.W., Lee, L.Z. \& Toupin, C. 1993. Suitability of plastic films for modified atmosphere packaging of fruits and vegetables. Journal of Food Science 58, 6: 1365-1370.

Francis, G.A., Thomas, C. \& O'Beirne, D. 1999. The microbiological safety of minimally processed vegetables. International Journal of Food Science and Technology 34: 1-22.

Gorny, J.R. 1997a. Modified atmospheres packaging and the fresh cut revolution. Perishables Handling Newsletter 90: 4-5.

Gorny, J.R. 1997b. A summary of CA and MAP requirements and recommendations for fresh-cut (minimally processed) fruits and vegetables. CA'97 Proceedings.
Vol. 5. Fresh-cut Fruits and Vegetables and MAP. University of California, Davis, USA. $168 \mathrm{p}$.

Hardenburg, R.E., Watada, A.E. \& Wang, C.Y. 1986. The commercial storage of fruits, vegetables, and florist and nursery stocks. USDA Agriculture Handbook No. $66.130 \mathrm{p}$.

Kader, A.A. 2002. Postharvest biology and technology: an overview. In: Kader, A.A. (ed.). Postharvest technology of horticultural crops. Third edition. Publication 3311. Division of Agriculture and Natural Resources, University of California, USA. 534 p.

Kim, G.H. \& Wills, R.B.H. 1995. Effect of ethylene on storage life of lettuce. Journal of the Science of Food and Agriculture 69: 197-201.

Le Ster, F. 1995. Treatments applicable to chopped fruit and vegetables. Refrigeration. In: Mulet, A. \& Serra M. (eds.). Minimally processing of fruit and vegetables. $p$. 145-147.

Mannapperuma, J.D., Zagory, D., Singh, R.P. \& Kader, A.A. 1989. Design of polymeric packages for modified atmosphere storage of fresh produce. In: International controlled atmosphere research conference. Fifth proceedings Vol. 2 - Other commodities and storage recommendations. 14-16 June, Wenatchee, USA. p. 225233.

Marth, E.H. 1998. Extended shelf life of refrigerated foods: microbiological quality and safety. Food Technology 52 , 2: 57-62.

Mateos, M., Ke, D., Kader, A. \& Cantwell, M. 1993. Differential responses of intact and minimally processed lettuce to carbon dioxide atmospheres. Acta Horticulturae 343: 171-174.

Mattila, M., Ahvenainen, R., Hurme, E. \& Hyvönen, L. 1993. Respiration rates of some minimally processed vegetables. In: Systems and operation for post-harvest quality. Post-harvest treatments of fruit and vegetables. COST 94 Commission of the European Community. Belgium. p. 135-145.

Saltveit, M.E. 1982. Procedures for extracting and analyzing internal gas samples from plant tissues by gas chromatography. HortScience 17: 878-881.

Watada, A., Abe, K. \& Yamuchi, N. 1990. Physiological activities of partially processed fruits and vegetables. Food Technology 44, 5: 116-122.

Yang, S.F. \& Pratt, H.K. 1978. The physiology of ethylene in wounded plant tissues. In: Kahl, G. (ed.). Biochemistry of wounded plant tissues. Walter de Gruyter and Co., Berlin. p. 595-622. 